\title{
Analisis Respon Siswa SMK PGRI Sukoharjo Terhadap Pembelajaran Matematika Melalui Media Online
}

\author{
Tri Puji Astuti a, ${ }^{\star}$, Joesefin Indriayudea ${ }^{a, 2}$, Titich Estu Hastutia,3, Annisa Prima Exactaa,4 \\ ${ }^{a}$ Pendidikan Matematika, Universitas Veteran Bangun Nusantara, Sukoharjo, Indonesia \\ ${ }^{1}$ ptri651@gmail.com, ${ }^{2}$ joe110@gmail.com, ${ }^{3}$ titichestu@gmail.com, ${ }^{3}$ annisa.p.exacta@ gmail.com \\ * Correspondence Author
}

Diterima 10 Desember 2020; Disetujui 18 Maret 2021; Diterbitkan 19 Maret 2021

\begin{abstract}
The objective of this study is to find out the results of the analysis of student responses to mathematics learning through online media. This is descriptive quanlitative study that focuses on learning evaluation using online media. The population are students of class X TBSM, XI OTKP, and XI AKL SMK PGRI Sukoharjo. The sample are selected using simple random sampling technique. The data collection instrument using an online learning questionnaire and for the data analysis use descriptive statistics. The results show that student learn using online media as very effective (7.90\%), most of them rated it as effective $(34.2 \%)$ and ordinary (28.9\%). There are also students who considered online learning as ineffective (21.1\%) and very ineffective (7.90\%). To make mathematics learning even more effective, teachers or educators are further expected to apply the seven principles given by students, namely (1) Learning through video calls, (2) Providing brief learning materials, (3) Providing videos in delivering material, (4) Minimize sending material in the form of large files to save mobile data, (5) Material selection in the video must be based on language criteria that is easy to understand, (6) Keep providing material before assignments, (7) Reducing assignments
\end{abstract}

KEYWORDS

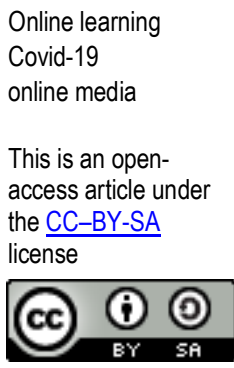

\section{Pendahuluan}

Pandemi Covid-19 melanda negara di belahan dunia, salah satunya negara kita yaitu Indonesia. Data terbaru dari World Health Organization (WHO) tanggal 21 Oktober 2020, sebanyak 217 negara telah terjangkit Covid-19, diantaranya 41.189 .939 terkonfirmasi positif dan 1.131.643 meninggal dunia. Covid-19 merupakan penyakit menular, yang berarti dapat menyebar baik secara langsung maupun tidak langsung, dari satu orang ke orang lain. Kondisi ini menyerang sistem pernapasan seperti hidung, tenggorokan, dan paru-paru. Rumitnya penanganan wabah ini, masih belum bisa optimal dikarenakan testing belum bisa melampaui standar World Health Organization (WHO) untuk menyembuhkan pasien Covid-19. Sehingga sampai saat ini pemerintah belum bisa memberikan keputusan kapan proses belajar mengajar kembali dilaksanakan secara tatap muka yang sebelumnya pemerintah memutuskan untuk meliburkan peserta didik dan memindahkan proses belajar mengajar secara tatap muka menjadi secara online atau dalam jaringan (daring) sesuai kebijakan Work From Home (WFH). Namun, pelaksanaan proses pembelajaran secara online memiliki kendala. Salah satu kendala terberat dalam pembelajaran daring adalah mengajar mata pelajaran matematika karena akan sulit untuk peserta didik memahami materi bahkan saat pembelajaran tatap muka, masih ada peserta didik yang belum bisa memahami materi tersebut.

Problematika saat ini adalah masih banyak peserta didik yang menganggap matematika pelajaran yang sulit. Menurut pendapat (Auliya, 2016), matematika mayoritas dianggap sebagai pelajaran yang sulit. Karena karakteristik matematika yang bersifat abstrak, logis, sistematis, dan penuh dengan lambang serta rumus. Kesulitan yang ada dalam mata pelajaran matematika 
menuntut kreativitas guru mata pelajaran matematika untuk mengembangkan inovasi pembelajaran, baik dalam hal metode maupun media yang digunakan.

Penggunaan media online atau media berbasis multimedia merupakan salah satu solusi untuk membuat peserta didik mampu memahami materi pelajaran dengan baik. Hal ini sejalan dengan hasil penelitian (Ibrahim \& Suardiman, 2014) yang menunjukkan bahwa ada pengaruh positif penggunaan e-learning terhadap motivasi dan prestasi belajar peserta didik di SD Negeri Tahunan Yogyakarta. Pembelajaran daring menggunakan media online juga telah diterapkan di SMK PGRI Sukoharjo sejak mulai diberlakukannya Work From Home (WFH) pada 16 Maret 2020 selama masa pandemi covid-19. Media online yang digunakan seperti youtube, whatsapp group, google classroom, dan google meet. Materi diberikan dalam bentuk powerpoint, video singkat, dan bahan bacaan. Namun dalam pelaksanaan pembelajaran daring tersebut, perlu dilakukan evaluasi agar didapatkan langkah perbaikan jelas yang berbasis data. Hal itulah yang mendasari penulis untuk mengetahui gambaran efektivitas pembelajaran daring menggunakan media online pada mata pelajaran matematika kelas X TBSM, XI OTKP, dan XI AKL SMK PGRI Sukoharjo.

\section{Metode}

Penelitian ini menggunakan jenis metode penelitian kuantitatif deskriptif. Tujuannya untuk mengetahui gambaran efektivitas pembelajaran daring pada pelajaran matematika menggunakan media online. Populasi penelitian adalah peserta didik kelas X TBSM, XI OTKP, dan XI AKL SMK PGRI Sukoharjo yang diajar mata pelajaran matematika menggunakan metode daring. Sampel yang menjadi responden penelitian ini yaitu 38 peserta didik atau setengah dari jumlah peserta didik kelas X TBSM, XI OTKP, dan XI AKL SMK PGRI Sukoharjo, dan menggunakan teknik simple random sampling dengan mempertimbangkan homogenitas populasi. Instrumen pengumpulan data menggunakan kuesioner yang berisi jenis pertanyaan tertutup, semi tertutup, dan terbuka yang dibagikan menggunakan google form. Analisis data menggunakan statistik deskriptif dengan bantuan komputerisasi.

\section{Hasil Dan Pembahasan}

Jumlah sampel yang menjadi responden dalam penelitiana ini sebanyak 38 peserta didik yang terdiri dari $76 \%$ jenis kelamin perempuan dan $24 \%$ jenis kelamin laki-laki. Sebagian besar responden berasal dari kecamatan Nguter (21\%) dan kecamatan sekitarnya, yaitu Polokarto (18\%), Baki (10\%), Grogol (10\%), Sukoharjo (10\%), Bendosari (8\%), Mojolaban (5\%), Weru (3\%), serta ada responden berasal dari kecamatan Jatipuro (3\%), Pracimantoro (3\%), Wonoharjo (3\%), Wonosari (6\%), dan Wonogiri (3\%). (Lihat Gambar 1).

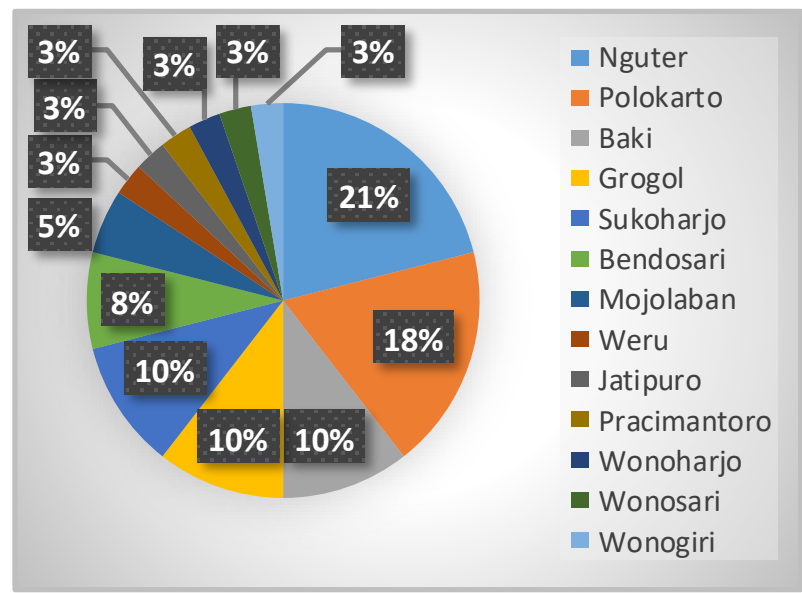

Gambar 1. Domisili Peserta Didik 
Domisili peserta didik yang berada pada wilayah kecamatan sekolah dan luar kecamatan sekolah telah menunjukkan bahwa sekolah ini masuk ke aturan dalam penerimaan peserta didik, yaitu sesuai dengan lokasi tempat tinggal anak atau aturan tentang sistem zonasi dan jalur prestasi untuk lokasi tempat tinggal anak yang berada di luar zonasi. Aturan terkait sistem zonasi dan jalur prestasi ini tertuang dalam Peraturan Menteri Pendidikan dan Kebudayaan (Permendikbud) Nomor 51 Tahun 2018 tentang Penerimaan Peserta Didik Baru Pada TK, SMP, SMA, dan SMK. Dalam aturan tersebut dijelaskan bahwa sekolah di bawah pemerintah dalam proses Penerimaan Peserta Didik Baru (PPDB) wajib menerima 90\% peserta didik baru yang berasal dari dekat sekolah dan 5\% dari jalur prestasi di luar zonasi. Tetapi, sekolah ini merupakan sekolah swasta yang tidak menerapkan aturan zonasi tersebut.

Selama pemberlakuan Work From Home (WFH) ini, responden paling banyak menghabiskan waktu dalam sehari dengan bermain handphone. Mereka mengatakan selama Work From Home (WFH), tidak bisa menahan diri untuk bermain handphone karena dalam pembelajaran daring dan mengerjakan tugas mereka menggunakan handphone. Jadi, disela pembelajaran daring dan mengerjakan tugas itulah mereka menggunakan media sosial untuk chatting dengan temannya atau bermain game. Tetapi, hanya sebagian peserta didik yang memanfaatkan handphone mereka untuk mengerjakan tugas. Gambar 2 menunjukkan aktivitas lain yang mereka kerjakan adalah membereskan rumah untuk membantu orang tua mereka.

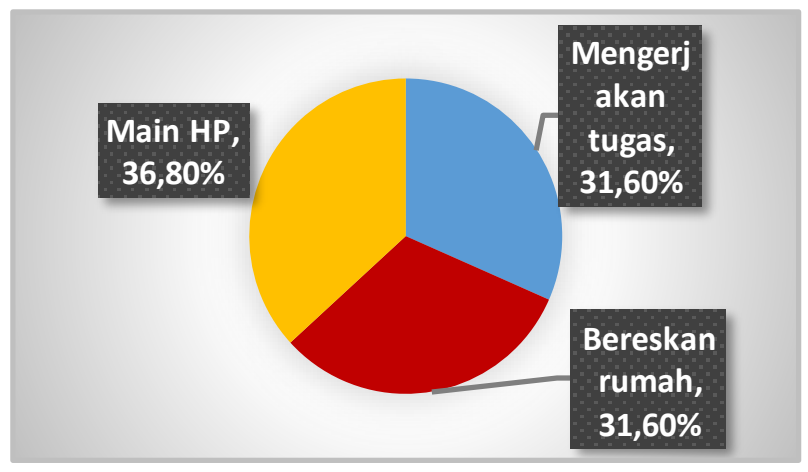

Gambar 2. Aktivitas yang Paling Banyak Dikerjakan Selama WFH

Penggunaan handphone dengan durasi yang terlalu lama dan intensitas yang terlalu sering karena digunakan membuka media sosial, pembelajaran daring, dan mengerjakan tugas mengakibatkan mereka mengalami keluhan fisik paling banyak berupa mata kelelahan $(47,4 \%)$. Mereka juga mengeluhkan sering mengantuk $(39,5 \%)$, sakit kepala $(28,9 \%)$, sulit istirahat $(18,4 \%)$, badan pegal $(18,4 \%)$, dan nafsu makan terganggu $(7,9 \%)$. Meskipun demikian, sebanyak 26,3\% peserta didik merasa tidak ada keluhan fisik. (Lihat Gambar 3).

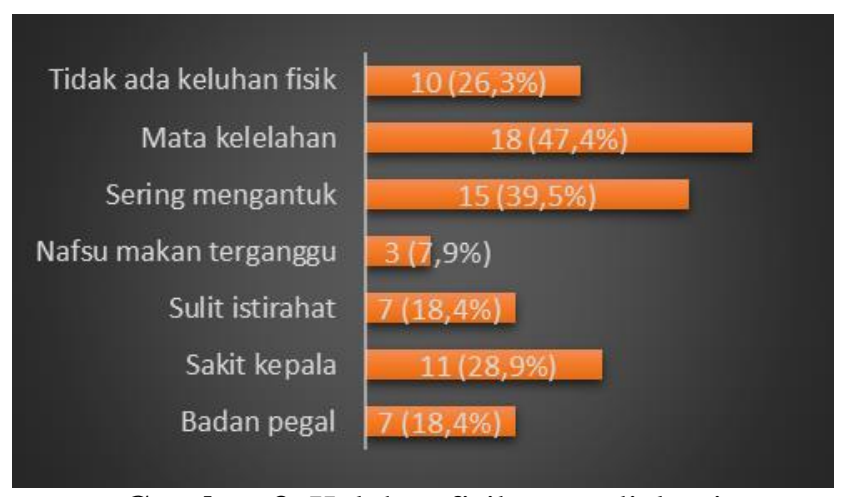

Gambar 3. Keluhan fisik yang dialami

Keluhan fisik tersebut merupakan dampak dari penggunaan gadget yang berlebihan. Hasil penelitian ini sesuai dengan hasil penelitian yang sebelumnya dilakukan oleh (Sidabutar et al., 
2019) yang menunjukan bahwa penggunaan gadget dapat menyebabkan iritasi matadan sakit kepala. Menurut Ilias dalam (Bawelle et al., 2016), mata lelah dapat terjadi jika mata fokus kepada objek terlalu dekat dalam waktu yang lama dan otot-otot mata bekerja lebih keras untuk melihat objek terutama jika disertai dengan pencahayaan yang menyilaukan.

Selain keluhan fisik, peserta didik juga mengalami keluhan psikologis (Gambar 4). Keluhan yang paling banyak dialami yakni perasaan ingin semuanya segera berakhir $(57,9 \%)$, mereka juga merasakan bosan $(44,7 \%)$, pusing $(18,4 \%)$, resah $(7,9 \%)$, dan khawatir $(5,3 \%)$. Namun, ada diantara mereka yang sama sekali tidak merasakan keluhan psikologis $(31,6 \%)$.

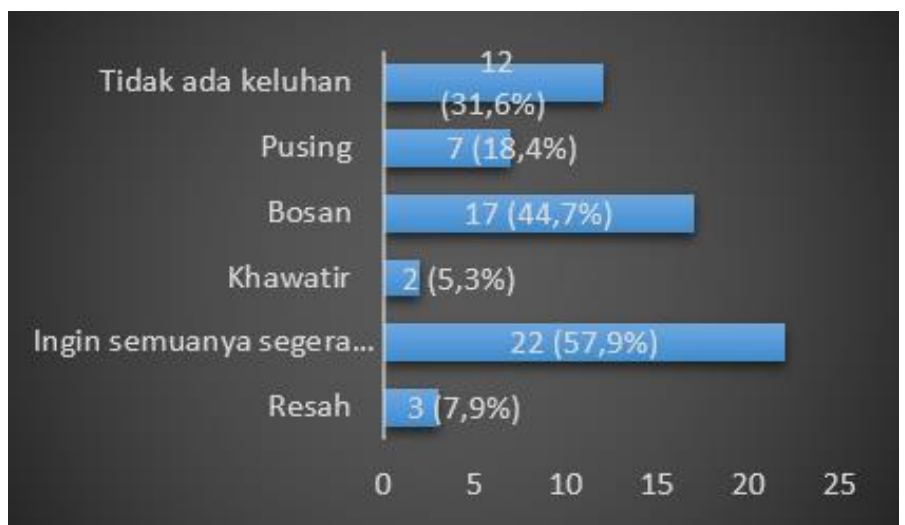

Gambar 4. Keluhan Psikologis yang Dialami Peserta Didik

Hasil penelitian deskriptif menggambarkan beberapa peserta didik yang menyukai pembelajaran menggunakan daring $(5,30 \%)$, tetapi sebagian peserta didik menyukai model pembelajaran blended (perpaduan tatap muka dengan daring) sebesar 13,20\%, serta sebagian besar peserta didik menyatakan menyukai pembelajaran dengan tatap muka yakni sebesar $81,60 \%$. (Lihat Gambar 5).

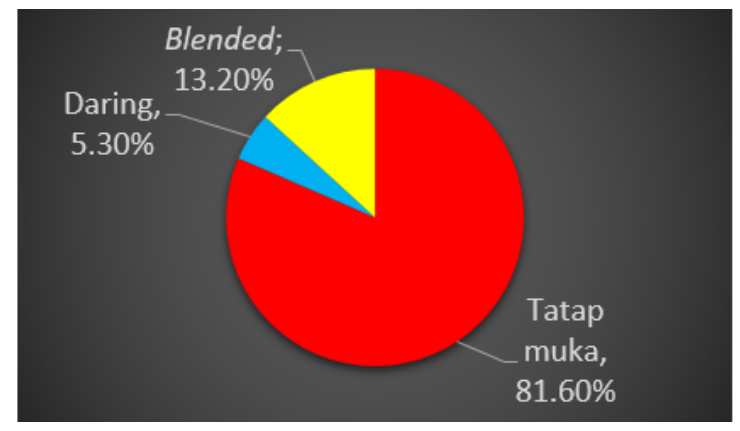

Gambar 5. Model Pembelajaran yang Disukai

(Hartanto, 2016) mengungkapkan bahwa teknologi informasi dan telekomunikasi yang murah dan mudah akan menghilangkan batasan ruang dan waktu yang selama ini membatasi dunia pendidikan. Beberapa konsekuensi logis yang terjadi dalam penggunaan e-learning, antara lain peserta didik dapat dengan mudah mengakses materi pembelajaran dimanapun tanpa terbatas lagi pada batasan tempat dan waktu, peserta didik dapat dengan mudah berguru dan berdiskusi dengan para tenaga ahli atau pakar di bidang yang diminatinya, materi pembelajaran bahkan dapat dengan mudah diambil di berbagai penjuru dunia tanpa tergantung pada dimana peserta didik belajar. Berbagai peluang tersebut masih menghadapi tantangan baik dari biaya, kesiapan infrastruktur teknologi informasi, masyarakat, dan peraturan yang mendukung terhadap kelangsungan e-learning.

Meskipun banyak kemudahan yang diberikan pembelajaran daring melalui internet, namun hasil penelitian ini menunjukkan peserta didik lebih menyukai pembelajaran tatap muka. Berdasarkan hasil wawancara dengan beberapa peserta didik, terdapat adanya tiga reaksi mereka terhadap perubahan pembelajaran tatap muka ke pembelajaran daring, yaitu menolak, tawar 
menawar, dan menerima. Mungkin sampai saat ini peserta didik lebih menyukai pembelajaran tatap muka karena mereka masih dalam tahap menolak. Hal itu disebabkan karena untuk penyampaian materi khususnya materi matematika lebih mudah untuk dipahami ketika pembelajaran tatap muka berlangsung. Tetapi, saat ini peserta didik juga telah menerima pembelajaran daring, karena peserta didik sudah mampu menyesuaikan diri dengan pembelajaran daring.

Menurut pendapat (Kuntarto, 2017) menunjukkan bahwa model pembelajaran daring telah memberikan pengalaman baru yang lebih menantang daripada model pembelajaran konvensional (tatap muka). Tak terbatas waktu dan tempat belajar memberikan peserta didik kebebasan untuk memilih saat yang tepat dalam pembelajaran berdasarkan kepentingan mereka, sehingga kemampuan untuk menyerap bahan pembelajaran menjadi lebih tinggi daripada belajar di dalam kelas, sedangkan (Wardani et al., 2018) menyatakan bahwa dengan blended learning dapat membuat peserta didik untuk lebih aktif dalam proses pembelajaran dikelas dan online, dapat membuat proses pembelajaran menjadi lebih menyenangkan. Apabila guru dapat membuat proses pembelajaran menjadi lebih menyenangkan. Apabila guru dapat membuat proses pembelajaran tersebut menyenangkan, maka peserta didik akan tertarik untuk mengikuti proses pembelajaran.

Gambar 6 menunjukkan media daring yang paling disukai peserta didik secara berturut-turut yakni WhatsApp Group (89,5\%), Google Meet (23,7\%), Google Classroom (15,8\%), Youtube (7,9\%), dan Zoom Meeting (2,6\%). Mereka menyukai media tersebut karena dianggap mudah dan praktis digunakan. Selain itu, karena tidak terlalu banyak menyita pulsa kouta. Meskipun demikian, mereka masih menginginkan adanya pertemuan tatap muka via online seperti Google meet sebagaimana yang mereka sarankan dalam penelitian ini. Hanya saja kendala kuota dan akses jaringan terbatas, sehingga mereka berharap pihak pemerintah menyediakan fasilitas daring yang efektif dan tidak membebani.

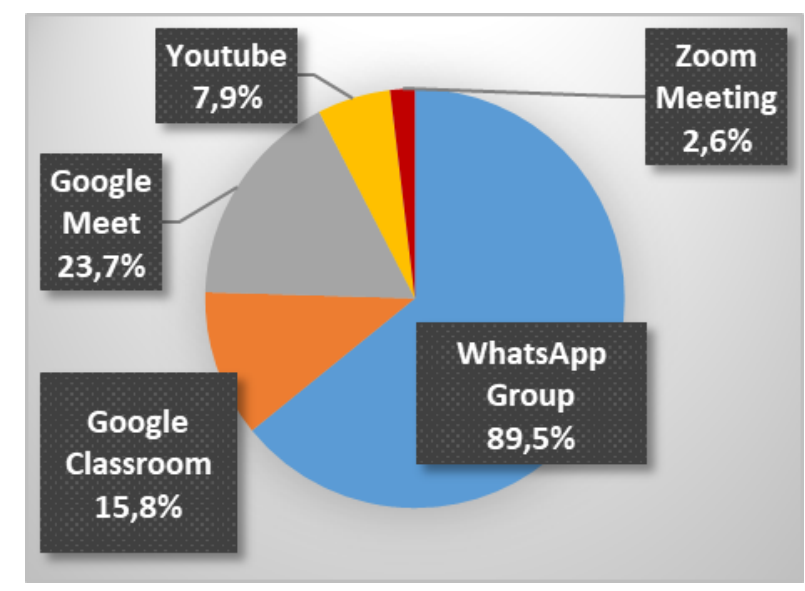

Gambar 6. Media Daring yang Disukai

(Suhery et al., 2020) mengungkapkan bahwa kelebihan dari model pembelajaran daring adalah tersedianya fasilitas e-moderating, dapat menggunakan bahan ajar yang terstruktur dan terjadwal melalui internet, peserta didik dapat mereview bahan ajar dimana saja, dapat mencari informasi tambahan di internet, dapat melakukan diskusi, dan relatif lebih efisien. Selain itu, dapat meningkatkan keaktifan dan kemandirian peserta didik dalam proses pembelajaran.

Pengajar diharapkan dapat menyajikan materi melalui web yang menarik dan diminati, melayani bimbingan dan komunikasi melalui internet, dan kecakapan lain yang diperlukan (Mahnun, 2018). Hasil penelitian (Yensy, 2020) menunjukkan bahwa penggunaan whatsapp group sebagai media pembelajaran memberikan dampak yang positif terhadap peningkatan hasil belajar, serta menumbuhkan sikap kreatif pada peserta didik ataupun mahasiswa. 
Metode pembelajaran daring yang peling disukai peserta didik secara berturut-turut sebagai berikut: ceramah dengan guru yang menjelaskan, diskusi, penugasan individu, video, kuis, dan penugasan kelompok. (Lihat Gambar 7).

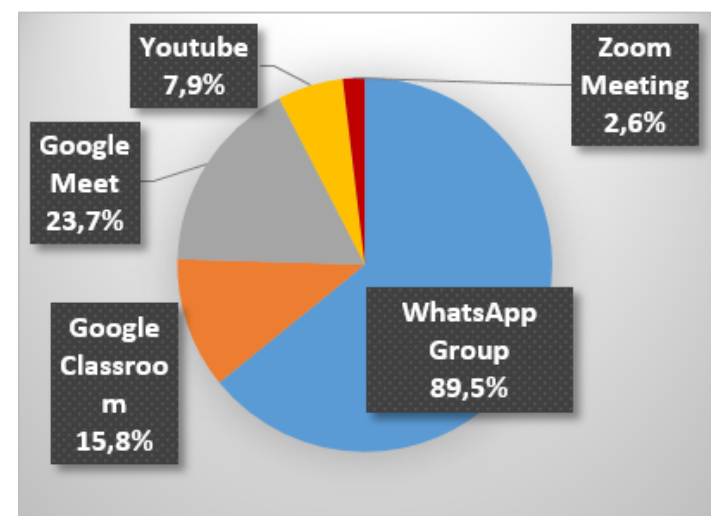

Gambar 7. Metode Pembelajaran yang Disukai

Memotivasi peserta didik baik secara intrinsik maupun ekstrinsik, penggunaan e-learning dalam proses pembelajaran harus memperhatikan prinsip-prinsip penggunaan serta kelebihan dan kekurangan e-learning (Sari, 2015). Proses pembelajaran dengan menggunakan e-learning hendaknya tidak menempatkan peserta didik hanya sebagai "pendengar" atau "penonton" saja, melainkan juga mendorong partisipasi aktif dari peserta didik untuk berinteraksi, berdialog, bekerja sama, berbagi dan membangun pengetahuan bersama. Selain itu, dalam menggunakan $e$ learning guru harus kreatif dan inovatif serta memiliki sikap kritis dalam memilih bahan pembelajaran, beretika baik dalam memanfaatkan bahan tersebut, menghindari penggunaan gambar-gambar atau audio yang kurang relevan dengan materi pembelajaran, mendorong partisipasi aktif dari peserta didik, memberikan perhatian dan menyediakan waktu lebih terhadap peserta didik yang mengalami kesulitan dalam menggunakan e-learning, profesional serta memiliki motivasi untuk terus belajar dan meningkatkan pengetahuan dan keterampilan.

Hasil penelitian (Hanum, 2013) bahwa interaksi pembelajaran dapat berjalan apabila terdapat pengelola pembelajaran (guru), sumber belajar, subjek pembelajar, interaksi antara pengajar/guru. Pengelolaan pembelajaran dapat dilakukan oleh guru, sehingga guru memberikan peran aktif dalam sistem pembelajaran termasuk dalam e-learning. Meskipun metode ceramah sangat tidak efisien untuk dilaksanakan saat ini, tetapi peserta didik menginginkan metode ceramah diterapkan saat pembelajaran daring.

Kendala yang dihadapi peserta didik selama pembelajaran daring, yakni jaringan internet tidak stabil, pulsa kuota terbatas, lebih senang belajar dengan pembelajaran tatap muka, tugas semakin banyak, sulit fokus, dan aplikasi yang rumit. (Lihat Gambar 8).

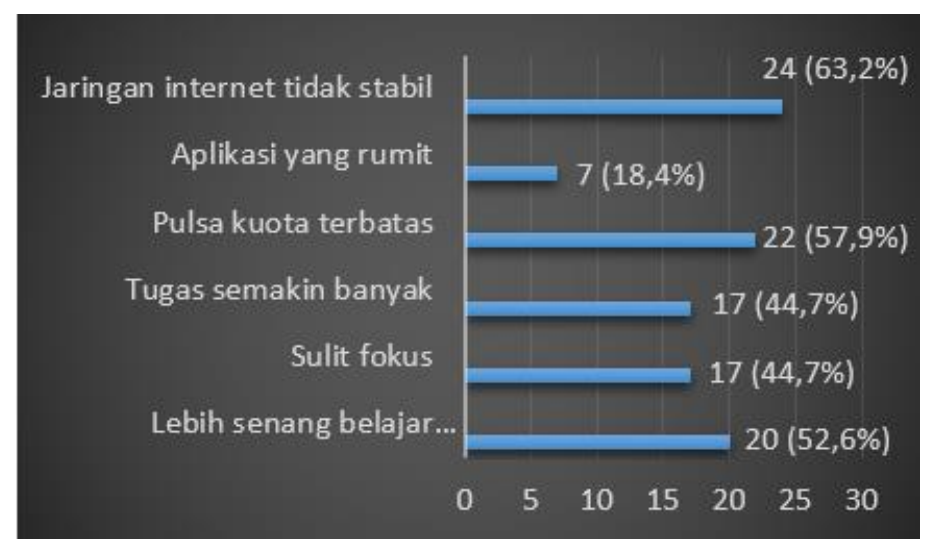

Gambar 8. Kendala yang Dihadapi Selama Daring 
Menurut Wiliam Horton dalam (Setiawardhani, 2013) bahwa e-learning merupakan pembelajaran berbasis web yang bisa diakses dari internet, maka ketersediaan akses internet sangat dipelukan dalam pembelajaran e-learning, karena karakteristik pembelajaran ini selalu menggunakan dan memanfaatkan jaringan internet. Secara umum, kecepatan akses jaringan internet di Indonesia relatif lambaat, ketersediaan jaringan internet yang masih terbatas dan harga untuk mengakses internet relatif mahal sehingga menjadi hambatan bagi pembelajaran $e$ learning.

Peserta didik menerima kenyataan bahwa saat ini sedang diberlakukan work from home yang menuntut untuk dilakukan pembelajaran daring. Peserta didik menilai pembelajaran matematika menggunakan media online sangat efektif $(7,90 \%)$, sebagian besar mereka menilai efektif $(34,20 \%)$ dan menilai biasa saja $(28,90 \%)$. Meskipun ada juga peserta didik yang menganggap pembelajaran daring tidak efektif $(21,10 \%)$ dan menilai sangat tidak efektif $(7,90 \%)$. (Lihat Gambar 9).

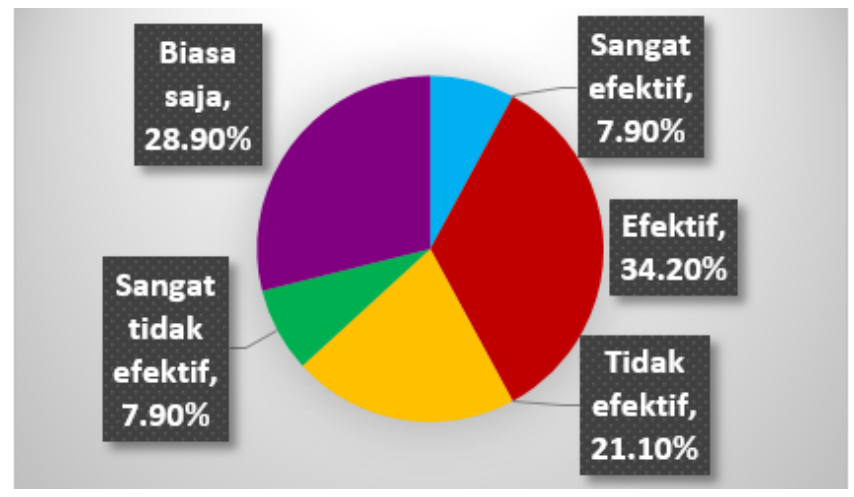

Gambar 9. Penilaian Keefektifan Pembelajaran Daring

Penggunaan media online dalam pembelajaran daring memungkinkan peserta didik untuk memiliki semangat yang tinggi untuk belajar dan mengerjakan tugas. Penggunaan internet pada peserta didik secara signifikan dapat memengaruhi motivasi peserta didik dalam menggunakan e-learning (Sianturi, 2018).

Menurut (Puspitasari et al., 2018) terdapat pengaruh yang signifikan penggunaan media pembelajaran terhadap motivasi peserta didik. Hal senada disampaikan oleh (Ibrahim \& Suardiman, 2014) bahwa ada pengaruh positif penggunaan e-learning terhadap motivasi dan prestasi belajar peserta didik di SD Negeri Tahunan Yogyakarta. Menurut (Aurora \& Effendi, 2019) juga terdapat pengaruh yang positif dan signifikan antara penggunaan media pembelajaran e-learning dengan motivasi belajar peserta didik. Hasil penelitian (Nadziroh, 2017) bahwa e-learning efektif dalam meningkatkan mutu pembelajaran, karena proses pembelajaran tidak hanya dalam satu waktu dan dalam ruangan saja.

Terdapat 7 saran yang diberikan oleh sampel penelitian supaya pembelajaran matematika kedepannya jauh lebih efektif, yakni pembelajaran melalui video call, pemberian materi pembelajaran yang ringkas, memberikan video dalam menyampaikan materi, meminimalisir mengirim materi dalam bentuk video berat untuk menghemat kuota, pemilihan materi dalam video harus berdasarkan kriteria bahasa yang mudah dipahami, tetap memberikan materi sebelum penugasan, mengurangi tugas.

Meskipun peserta didik lebih banyak menyukai pembelajaran secara tatap muka, namun mereka menerima kenyataan pembelajaran daring sebagai konsekuensi pembelakuan work from home dari pemerintah. Hal tersebut membuat mereka semakin sering dan semakin lama menggunakan handphone untuk daring dan untuk mengerjakan tugas pelajaran. Hal itu juga membuat mereka mengalami keluhan fisik terbanyak seperti mata kelelahan dan sakit kepala. Begitu pula dengan keluhan psikologis bahwa ingin semuanya segera berakhir. 


\section{Simpulan}

Inovasi pembelajaran yang dilakukan oleh guru matematika yakni dengan menggunakan media online membantu peserta didik menjalani pembelajaran daring selama pandemi covid-19 ini. Alhasil, peserta didik menilai pembelajaran matematika menggunakan media online sangat efektif $(7,9 \%)$, sebagian besar mereka menilai efektif $(34,2 \%)$ dan menilai biasa saja $(28,9 \%)$. Meskipun ada juga peserta didik yang menganggap pembelajaran daring tidak efektif $(21,1 \%)$ dan menilai sangat tidak efektif $(7,9 \%)$. Untuk membuat pembelajaran matematika lebih efektif lagi, kedepannya guru atau pendidik diharapkan menerapkan tujuh saran yang diberikan peserta didik, yakni (1) Pembelajaran melalui video call, (2) Pemberian matematika pembelajaran yang ringkas, (3) Memberikan video dalam menyampaikan materi, (4) Meminimalisir mengirim materi dalam bentuk video berat untuk menghemat kuota, (5) Pemilihan materi dalam video harus berdasarkan kriteria bahasa yang mudah dipahami, (6) Tetap memberikan materi sebelum penugasan, (7) Mengurangi tugas.

\section{Referensi}

Auliya, R. N. (2016). Kecemasan Matematika Dan Pemahaman Matematis. Jurnal Formatif. 6 (1): $12-22$.

Aurora, A. \& Efendi, H. 2019. Pengaruh PenggunaanMedia Pembelajaran E-Learning terhadap Motivasi Belajar Mahasiswa di Universitas Negeri Padang. Jurnal Teknik Elektro dan Vokasional. 5(2) : 11-16.

Bawelle, C. F. N., Lintong, F., \& Rumampuk, J. 2016.Hubungan Penggunaan Smartphone dengan Fungsi Penglihatan Pada Mahasiswa Fakultas Kedokteran Universitas Sam Ratulangi Manado Angkatan 2016. Jurnal e-Biomedik. 4(2) : 1-6.

Hartanto, W. 2016. Penggunaan E-learning Sebagai Media Pembelajaran. Jurnal Pendidikan Ekonomi. 10(1) : 1-18.

Ibrahim, D. S. \& Suardiman, S. P. 2014. Pengaruh Penggunaan E-learning Terhadap Motivasi dan Prestasi Belajar Matematika Siswa Sd Negeri Tahunan Yogyakarta. Jurnal Prima Edukasia. 2 (1) : 66-9.

Kuntarto, E. 2017. Keefektifan Model Pembelajaran Daring dalam Perkuliahan Bahasa Indonesia di Perguruan Tinggi. Journal Indonesia Language Education and Literature. $3(1): 53-65$.

Mahnun, N. 2018. Implementasi Pembelajaran Online dan Optimalisasi Pengelolaan Pembelajaran Berbasis Online di Perguruan Tinggi Islam Dalam Mewujudkan World Class University. IJIEM:Kajian Teori dan Hasil Penelitian Pendidikan. 1(1) : 29-36.

Nadziroh, F. 2017. Analisa Efektifitas Sistem Pembelajaran Berbasis E-Learning. Jurnal Ilmu Komputer dan Desain Komunikasi Visual. 2(1) : 1-14.

Puspitasari, P., Putri, P. S. J., \& Wuryani, W. 2018. Pengaruh Penggunaan Media Pembelajaran Terhadap Motivasi Belajar Mahasiswa IKIP Siliwangi. Jurnal Pendidikan Bahasa dan Sastra Indonesia. 1(2) : 227-232.

Sari, P. 2015. Memotivasi Belajar Dengan Menggunakan E-Learning. Jurnal Ummul Qura. 6(2) : 20-35.

Setiawardhani, R. T. 2013. Pembelajaran Elektronik (E-Learning) dan Internet dalam Rangka Mengoptimalkan Kreativitas Belajar Siswa. Jurnal Ilmiah Pendidikan Ekonomi. 1(2) : 82-96.

Sianturi, S. R., \& Lisum, K. 2018. Peningkatan Motivasi Belajar melalui Evaluasi E-Learning pada Institusi Keperawatan di Jakarta dan Depok. Jurnal Pendidikan Keperawatan Indonesia. 4(2) : 122-130. 
Sidabutar, L., Adhitya, T., Wong, F., Rici, M., \& Wibisono, Y. P. 2019. Analisis Penggunaan Game Online Mobile Terhadap Kesehatan Mata Pada Mahasiswa FTI UAJY. Proceeding SINTAK. 3 : 402-410.

Suhery., Putra, T. J., \& Jasmalinda. 2020. Sosialisasi Penggunaan Aplikasi Zoom Meeting dan Google Classroom Pada Guru di SDN 17 Mata Air Padang Selatan. Jurnal Inovasi Penelitian. 1(3) : 129-132.

Wardani, D. N., Toenlioe, A. J. E., \& Wedi, A. 2018. Daya Tarik Pembelajaran di Era 21 dengan Blended Learning. Jurnal Kajian Teknologi Pendidikan. 1(1) : 13-18.

Yensy, N. A. 2020. Efektifitas Pembelajaran Statistika Matematika Melalui Media Whatsapp Group Ditinjau Dari Hasil Belajar Mahasiswa (Masa Pandemi Covid 19). Jurnal Pendidikan Matematika Raflesia. 5(2) : 65-74. 